\title{
GLOSA DO WYROKU SĄDU APELACYJNEGO W WARSZAWIE Z DNIA 12 STYCZNIA 2010 R., SYGN. VI ACA 666/09 (NIEPUBLIKOWANY)
}

\author{
WYROK SĄDU APELACYJNEGO W WARSZAWIE \\ Z DNIA 12 STYCZNIA 2010 R., SYGN. VI ACA 666/09, \\ (NIEPUBLIKOWANY)
}

1. Sprawy z zakresu art. 80 Poś są sprawami gospodarczymi i z tego względu obowiązuje prekluzja dowodowa $\mathrm{z}$ art. 47912 § 1 k.p.c.

2. Zakaz wynikający z art. 80 Poś dotyczy treści reklamy, która nie powinna propagować określonego modelu konsumpcji, uznanego przez ustawodawcę za niepożądany, tj. sprzeczny z zasadami ochrony środowiska i zrównoważonego rozwoju.

Magister prawa, doktorant w Katedrze Prawa Ochrony Środowiska WPiA UMK w Toruniu. 
3. Dla zastosowania art. 80 Poś wystarczające jest wykorzystanie obrazu, który $\mathrm{w}$ powszechnym odbiorze stanowi element dzikiej przyrody, nawet jeśli przedstawienie danego elementu dzikiej przyrody następuje poprzez piktogram.

4. Art. 80 Poś wymaga, żeby pomiędzy reklamą lub innym rodzajem promocji towaru lub usługi a negatywnym wpływem na środowisko przyrodnicze musi istnieć normalny związek przyczynowy.

Sąd Apelacyjny w Warszawie, po rozpoznaniu na rozprawie w dniu 12 stycznia 2010 roku sprawy z powództwa Stowarzyszenia F.Z. w B. przeciwko Bankowi P. w W. o zaniechanie działań - oddala apelację.

\section{UZASADNIENIE}

Powód Stowarzyszenie F.Z. w B. wniósł o zaprzestanie reklamy przez Bank P. w W. sprzedaży towarów i usług z wykorzystaniem wizerunku dzikiej przyrody z naruszeniem prawa. Pozwany Bank P. w W. wniósł o oddalenie powództwa w całości i zasądzenie kosztów postępowania. Sąd I instancji postanowieniem z dnia 8 listopada 2008 r. ustanowił dla powoda pełnomocnika z urzędu, który pismem procesowym z dnia 29 grudnia 2008 r. sprecyzował powództwo i wniósł o:

1. nakazanie zaprzestania przez pozwanego reklamy i innego rodzaju promocji z udziałem wizerunku dzikiej przyrody w postaci żubra;

2. zasądzenie od pozwanego na rzecz ochrony środowiska kwoty 100.000 zł oraz kosztów postępowania. Następnie pełnomocnik powoda na rozprawie w dniu 8 stycznia 2009 r. cofnął powództwo w zakresie żądania zasądzenia kwoty $100.000 \mathrm{zl}$.

Wyrokiem z dnia 16 lutego 2009 r. Sąd Okręgowy w W. oddalił powództwo, umorzył postępowanie co do kwoty 100.000 zł oraz orzekł o kosztach postępowania. Powyższe rozstrzygnięcie oparte zostało na następujących ustaleniach faktycznych i prawnych. 
Stowarzyszenie F.Z. w B. wystąpiło z roszczeniem o zaprzestanie reklamy przez Bank P. w W. sprzedaży towarów i usług $\mathrm{z}$ wykorzystaniem wizerunku dzikiej przyrody z naruszeniem prawa (art. 80 ustawy Prawo ochrony środowiska). Stosowanie wizerunku dzikiej przyrody przez stronę pozwaną w logo firmy jest bezsporne. Ponadto strona powodowa oparła powództwo na art. 325 i art. 326 ustawy Prawo ochrony środowiska, a także art. 24 § 1 k.c. Następnie w piśmie precyzującym powództwo pełnomocnik powoda wskazał, iż pozwany powszechnie używa wizerunku dzikiej przyrody (żubra) jako symbolu w swojej działalności. Z uwagi na charakter działalności pozwanego używanie wizerunku żubra dla celów reklamowych jest bardzo duże, wizerunek ten znajduje się między innymi na bankomatach, kopertach, stronie internetowej, oddziałach Banku. Strona pozwana prowadzi działalność gospodarczą w zakresie szeroko rozumianych czynności bankowych. Logo Spółki jest powszechnie znane, nawiązuje do wizerunku dzikiej przyrody, przedstawia zarys żubra. Nie jest to jednak obraz żadnego konkretnego osobnika, lecz wizja graficzna. Używana jest przez Bank powszechnie w obrocie, w tym również w reklamach. Strona pozwana podejmuje proekologiczne działania, wspiera ochronę dzikiej przyrody przez przekazywanie dotacji na podmioty zajmujące się ochroną przyrody. Powód jako organizacja społeczna, statutowo zajmująca się sprawami ochrony środowiska, została na podstawie art. 328 ustawy Prawo ochrony środowiska upoważniona do żądania, w drodze roszczenia, zaprzestania prowadzenia reklamy lub innego rodzaju promocji towaru lub usługi, zawierającej treści propagujące model konsumpcji sprzeczny z zasadami ochrony środowiska i wymaganego zrównoważonego rozwoju, zwłaszcza przez wykorzystanie w tym celu obrazu naturalnej przyrody do zwiększenia popularności produktów lub usług negatywnie wpływających na środowisko. Celem tego przepisu jest stworzenie możliwości przeciwstawiania się działalności o charakterze reklamowym, kolidującej z wymaganiami ochrony środowiska.

Żądanie z art. 80 ustawy Prawo ochrony środowiska realizuje zakaz reklamy (innego rodzaju promocji) towaru (usługi) zawierającej treści propagujące model konsumpcji sprzeczny 
z zasadami ochrony środowiska i zrównoważonego rozwoju. W ocenie Sądu I instancji abstrakcyjna ocena przesłanek z art. 80 ustawy Prawo ochrony środowiska nie jest możliwa. Odpowiedź na pytanie - czy doszło do naruszenia opisanego wyżej zakazu, możliwa jest wyłącznie na podstawie analizy konkretnego stanu faktycznego. W przedmiotowej sprawie strona powodowa nie wykazała, że pozwany promował jakiekolwiek towary lub usługi, których oddziaływanie wpływałoby negatywnie na środowisko (model konsumpcji sprzeczny z zasadami ochrony środowiska i zrównoważonego rozwoju nie został udowodniony). Fakt używania przez Bank w logo zarysu żubra jest powszechnie znany i nie wymaga przeprowadzenia dowodu, aczkolwiek nie uzasadnia roszczeń strony powodowej oraz twierdzenia, że w takim przypadku dochodzi do wykorzystywania przez Bank obrazu dzikiej przyrody do promowania produktów i usług negatywnie wpływających na środowisko. Powód nie wskazał bowiem jakie konkretnie usługi bankowe czy też może inne czynności okołobankowe wpływają negatywnie na środowisko. Obowiązkiem powoda w myśl art. 6 k.c. jest wykazanie w sposób dostateczny powyższych okoliczności. Powołane twierdzenia i dowody w piśmie strony powodowej wskazują jedynie na fakt, iż pozwany w swej działalności korzysta piktogramu żubra, co jest powszechnie znane, brak jednak nadal jakichkolwiek dowodów, iż oddziałuje to negatywnie i w jaki sposób na przyrodę. Ponadto w art. 80 ustawy Prawo ochrony środowiska ustawodawca mówi o wizerunku dzikiej przyrody, sam zaś znak Banku jest piktogramem, tj. znakiem pisma, w tym wypadku przedstawiającym wizerunek żubra, nie odnoszącym się jednak do żadnego konkretnego zwierzęcia. Nie można więc także obu tych pojęć (wizerunek dzikiej przyrody oraz piktogramu) uznać za tożsame, a w szczególności twierdzić, że logo Banku wprost odwołuje się do konkretnego wizerunku dzikiej przyrody, a tylko wówczas w ocenie Sądu Okręgowego można byłoby badać - czy w niniejszej sprawie zachodzą przesłanki z art. 80 ustawy Prawo ochrony środowiska. Analogiczna sytuacja zachodzi w zakresie pozostałych roszczeń wskazanych przez stronę powodową, tj. wywodzonych z art. 24 $\S 1$ k.c. oraz art. 325 i art. 326 ustawy Prawo ochrony środo2/2011 wiska. Strona powodowa nie przedstawiła żadnych twierdzeń 
i okoliczności umożliwiających stwierdzenie naruszenia dóbr osobistych, jak i zaistnienia szkody w środowisku. W ocenie Sądu I instancji generalne sformułowania pozwu są niewystarczające do stwierdzenia czy faktycznie doszło do naruszenia przepisów wskazanych przez powoda. Dlatego też powództwo zostało oddalone, zaś w zakresie obejmującym cofnięcie pozwu - umorzono postępowanie.

Od wyroku z dnia 16 lutego 2009 r. apelację złożył powód. Skarżący zarzucił:

I. naruszenie prawa procesowego, tj. artykułu $233 \S 1$ k.p.c. przez przekroczenie granicy swobodnej oceny dowodów oraz naruszenie zasad logicznego rozumowania polegające na błędnym przyjęciu, że powód nie wykazał, iż pozwany wykorzystuje obraz dzikiej przyrody do promowania produktów i usług negatywnie wpływających na środowisko, co stanowi propagowanie modelu konsumpcji sprzecznego z zasadami ochrony środowiska i zrównoważonego rozwoju, w rozumieniu art. 80 ustawy Prawo ochrony środowiska,

II. naruszenie prawa materialnego, tj. art. 80 ustawy Prawo ochrony środowiska przez jego błędną wykładnię, a to przyjęcie, iż jedynie konkretny wizerunek dzikiej przyrody - odnoszący się do konkretnego zwierzęcia, nie zaś piktogram (logo) przedstawiający wizerunek żubra, umożliwia badanie, czy zachodzą przesłanki z art. 80 ww. ustawy.

Powód wniósł o: zmianę wyroku przez orzeczenie zgodne z żądaniem pozwu, ewentualnie o uchylenie zaskarżonego wyroku i przekazanie sprawy do rozpoznania Sądowi I instancji. Sąd Apelacyjny zważył, co następuje:

Apelacja nie zasługuje na uwzględnienie. Sąd II instancji uznając trafność ustaleń faktycznych i słuszność oceny dowodów dokonane przez Sąd Okręgowy, przyjmuje je za własne.

$\mathrm{W}$ celu prawidłowego rozstrzygania $\mathrm{w}$ sprawie należało przede wszystkim rozważyć, zasadność zarzutu prekluzji dowodowej, podniesionego przez pozwanego w odpowiedzi na pozew, czyli jakie skutki dla strony powodowej będzie miała treść art. $479^{12} \S 1$ k.p.c. ustanawiająca tzw. prekluzję dowodową w postępowaniu w sprawach gospodarczych. Art. $479^{12} \S 1$ k.p.c. stanowi, iż: „W pozwie powód jest obowiązany podać wszystkie 
twierdzenia oraz dowody na ich poparcie pod rygorem utraty prawa powoływania ich $\mathrm{w}$ toku postępowania, chyba że wykaże, że ich powołanie w pozwie nie było możliwe albo że potrzeba powołania wynikła później". Należy zauważyć, że powód w pozwie przytoczył jedynie twierdzenia na jego poparcie, natomiast nie dołączył do pozwu żadnych dowodów na ich poparcie. Dowody te zostały złożone dopiero $\mathrm{w}$ momencie wstąpienia do sprawy pełnomocnika z urzędu powoda wraz z pismem precyzującym stanowisko strony z dnia 29 grudnia 2009 r. W ocenie Sądu Apelacyjnego dowody te należało pominąć jako wniesione $\mathrm{z}$ naruszeniem art. $479^{12} \S 1$ k.p.c., ponieważ w sprawie nie wystąpiła ani przesłanka niemożliwości ich wcześniejszego powołania, ani też potrzeba ich powołania nie wynikła później. Zdaniem Sądu odwoławczego okolicznością która mogłaby świadczyć o niemożności wcześniejszego powołania dowodów nie jest fakt, iż dopiero w toku postępowania Sąd Okręgowy ustanowił dla strony powodowej pełnomocnika z urzędu, gdyż gdyby przyjąć taką interpretację omawianego przepisu nie miałby on zastosowania do stron nie reprezentowanych przez profesjonalnych pełnomocników, a takiej wykładni nie dałoby się pogodzić z literalnym brzemieniem przepisu, który nie różnicuje podmiotów składających pozwy w sprawach gospodarczych. Zatem lege non distinguente dotyczył on również powoda w początkowej fazie postępowania. W związku z powyższym uprawniony jest wniosek, że powód nie przedstawił $\mathrm{w}$ sprawie jakiegokolwiek dowodu na poparcie swych twierdzeń, a zatem nie sprostał wymaganiu z art. 6 k.c., co samo w sobie prowadzi do oddalenia powództwa w sprawie i uzasadnia oddalenie apelacji. Tym niemniej Sąd Apelacyjny zwraca uwagę, iż nawet przy przyjęciu, iż dowody przedstawione przez powoda nie podlegają oddaleniu jako sprekludowane, powództwo powoda także nie mogło zostać uwzględnione.

Wskazać zatem należy, że zakaz wynikający z art. 80 Prawa ochrony środowiska dotyczy treści reklamy (lub innego rodzaju promocji), która nie powinna propagować określonego modelu konsumpcji, uznanego przez ustawodawcę za niepożądany, tj. sprzeczny zasadami ochrony środowiska i zrównoważonego rozwoju. Uprawnionym jest więc wniosek, że ustawodawca przyznał 2/2011 roszczenie o zaniechanie reklamy, promocji produktu tylko w ta- 
kiej sytuacji, gdy podmiot reklamujący rozpowszechnia, popiera, propaguje model konsumpcji sprzeczny z zasadami ochrony środowiska i zrównoważonego rozwoju, wykorzystując do tego obraz dzikiej przyrody. Tym samym warunkiem, bez zaistnienia którego roszczenie nie może być realizowane, jest wykazanie, że reklama propaguje taki model konsumpcji, który nie tylko wpływa na środowisko naturalne, ale niszczy je, degraduje, prowadzi do zaburzenia równowagi. Nie wystarczy bowiem wykazanie, że reklama (lub inny rodzaj promocji) wykorzystuje obraz dzikiej przyrody.

Poza sporem pozostaje okoliczność, że logo pozwanej Spółki nawiązuje do wizerunku dzikiej przyrody, przedstawia zarys żubra. Zdaniem Sądu Okręgowego, logo pozwanego będące piktogramem nie przedstawia konkretnego wizerunku dzikiej przyrody, co wyłącza subsumcję na podstawie art. 80 powołanej ustawy. W ocenie Sądu II instancji dla zastosowania art. 80 ustawy Prawo ochrony środowiska nie ma znaczenia, że logo Banku nie odwołuje się wprost do konkretnego (rzeczywistego) wizerunku dzikiej przyrody. Wystarczające bowiem jest wykorzystanie w reklamie (promocji) obrazu, który w powszechnym odbiorze stanowi element dzikiej przyrody, nawet jeżeli przedstawienie danego elementu dzikiej przyrody następuje poprzez piktogram. Zatem w realiach rozpoznawanej sprawy dla zastosowania art. 80 ustawy koniecznym stało się wykazanie, że reklama (promocja) propaguje taki model konsumpcji, który nie tylko wpływa na środowisko naturalne, ale niszczy je, degraduje, prowadzi do zaburzenia równowagi. Temu obowiązkowi dowodowemu strona powodowa nie sprostała.

Zaznaczyć również należy, że obecnie nie ma w zasadzie produktów ani usług niewywołujących żadnego wpływu na przyrodę. Przy literalnej interpretacji przepisu art. 80 ustawy Prawo ochrony środowiska można byłoby dojść do wniosku, że zamiarem ustawodawcy była całkowita eliminacja obrazów dzikiej przyrody w reklamie gospodarczej, co pozostaje w sprzeczności z zasadą proporcjonalności zastosowanych środków do spodziewanych celów regulacji. Dlatego też, w ocenie Sądu Apelacyjnego, właściwą interpretacją powołanego przepisu jest zawsze odwołanie się do zakazu dotyczącego zawierania przez reklamy 
lub inny rodzaj promocji treści propagujących model konsumpcji sprzeczny z zasadami ochrony środowiska i zrównoważonego rozwoju. Trafnie zatem uznał Sąd I instancji, że powód nie udowodnił, że użycie w logo Banku wizerunku dzikiej przyrody propaguje model konsumpcji sprzeczny z zasadami ochrony środowiska i zrównoważonego odbioru, lub że produkty, usługi i czynności bankowe opatrzone logo pozwanego - mają niszczący, destruktywny wpływ na środowisko. Uwzględniając nawet twierdzenia i dowody (wbrew przedstawionej wyżej zasadzie prekluzji z art. $479^{12} \S 1$ k.p.c.) zawarte w piśmie strony powodowej z dnia 29 grudnia 2008 r. powyższe elementy nie zostały wykazane. Nie budzi wątpliwości, że między dwoma zdarzeniami - przyczyną i skutkiem - musi istnieć normalny związek przyczynowy. Ustalanie „normalności” powinno zaś odbywać się według kryteriów zobiektywizowanych, które pozwalają przyjąć, że zwykle, najczęściej określone zdarzenie późniejsze (skutek) jest następstwem zdarzenia wcześniejszego (przyczyny). Odnosząc powyższe do realiów rozpoznawanej sprawy nie istnieje „normalne" następstwo pomiędzy np. udzieleniem kredytu (reklamowanego, promowanego z użyciem logo Banku, które odwołuje się do wizerunku dzikiej przyrody) a degradacją środowiska. W konsekwencji, wbrew stanowisku skarżących, ocena materiału dowodnego zgromadzonego w sprawie jest poprawna, zgodna $\mathrm{z}$ regułami art. $233 \S 1$ k.p.c.

Tym samym w sprawie nie zaistniały przesłanki do zastosowania art. 80 ustawy Prawo ochrony środowiska, który zakazuje reklamy (promocji) towaru lub usługi, która zawiera treści propagujące model konsumpcji sprzeczny z zasadami ochrony środowiska i zrównoważonego rozwoju, a w szczególności wykorzystuje obraz dzikiej przyrody do promowania produktów i usług negatywnie wpływających na środowisko przyrodnicze. Ponadto w ocenie Sądu odwoławczego w ustawie Prawo ochrony środowiska nie chodzi o to, aby zabronić prawa do korzystania ze środowiska - w tym również do wykorzystywania obrazów dzikiej przyrody, ale aby korzystać z niego w określonych granicach, np. nie wykorzystywać obrazu dzikiej przyrody i nie propagować modelu nadmiernej konsumpcji, niszczącej, degradującej środo2/2011 wisko naturalne. 
Z tych przyczyn Sąd Apelacyjny na podstawie art. 385 k.p.c. orzekł jak w sentencji. O kosztach postępowania odwoławczego postanowiono stosownie do treści art. 98 § 1 i 3 k.p.c.

\section{GLOSA}

Komentowany wyrok zasługuje na uwagę z kilku względów. Po pierwsze, sprawy z zakresu ochrony środowiska nie są zbyt często rozpoznawane przez sądy powszechne. Po drugie, Sąd w prezentowanym wyroku przyjął, że sprawy z art. 80 Prawa ochrony środowiska ${ }^{1}$ to sprawy gospodarcze. Po trzecie, Sąd podjął się zakreślenia zasad odpowiedzialności w związku z naruszeniem zakazu z art. 80 Poś. Po czwarte, Sąd zajął się rolą prawa $\mathrm{w}$ ochronie środowiska. Po piąte, o ile sam wyrok odpowiada prawu, o tyle jego uzasadnienie budzi pewne wątpliwości, co w kontekście wspomnianych powyżej powodów wzmaga potrzebę jego omówienia, zwłaszcza że wyrok nie został opublikowany.

Z aprobatą należy przyjąć pogląd wyrażony przez sąd, że w sprawach z art. 80 Poś obowiązuje prekluzja dowodowa $\mathrm{z}$ art. $479^{12} \S 1$ k.p.c. ${ }^{2}$ Tym samym sąd potwierdził to, że sprawy te należą do spraw gospodarczych z zakresu ochrony środowiska, a przez to winny być rozpatrywane przez sądy gospodarcze. Zgodnie bowiem z treścią art. $4791 \S 2$ pkt 2 k.p.c. sprawami gospodarczymi są także: „sprawy przeciwko przedsiębiorcom o zaniechanie naruszania środowiska i przywrócenie do stanu poprzedniego lub naprawienie szkody z tym związanej oraz zakazanie lub ograniczenie działalności zagrażającej środowisku".

Niemniej, w doktrynie w kwestii statusu spraw z art. 80 Poś pojawiały się różne poglądy. W zasadzie można wyodrębnić

1 Ustawa z dnia 27 kwietnia 2001 roku Prawo ochrony środowiska, t.j. Dz. U. z 2008 r. Nr 25, poz. 150 ze zm., dalej cyt.: Poś.

2 Ustawa z dnia 17 listopada 1964 roku Kodeks postępowania cywilnego, Dz. U. z 1964 r. Nr 43, poz. 296 ze zm., dalej cyt.: k.p.c. 
dwa rodzaje stanowisk ${ }^{3}$. Pierwsza grupa przyjmuje, że w tych sprawach orzeka sąd cywilny, a nie stosuje się przepisów o postępowaniu w sprawach gospodarczych, ponieważ sprawy te nie są sprawami przeciwko przedsiębiorcy o zaniechanie naruszania środowiska i przywrócenia stanu poprzedniego lub naprawienie szkody z tym związanej oraz zakazanie lub ograniczenie działalności zagrażającej środowisku, a przez to trudno wykazać związek pomiędzy sprawami z art. 80 Poś a normą wyrażoną w art. $479^{1} \S 2$ pkt 2 k.p.c. ${ }^{4}$

Drugie z reprezentowanych stanowisk zalicza te sprawy do spraw gospodarczych z zakresu ochrony środowiska. Na uzasadnienie podaje się, że ustawodawca świadom był skali zagrożeń, jakie dla środowiska stanowi działalność gospodarcza. W tym wypadku istotne znaczenia ma dynamika postępowania w sprawach gospodarczych. Poza tym z treści art. $479{ }^{1} \S 2$ pkt 2 k.p.c. można wyróżnić dwie zasadnicze kategorie spraw: pierwsza, tj. o zaniechanie naruszania środowiska i przywrócenie do stanu poprzedniego lub naprawienie szkody z tym związanej i druga, tj. o zakazanie lub ograniczenie działalności zagrażającej środowisku, który koresponduje z zakazem wyrażonym w art. 80 Pośs $^{5}$.

Na tle powyższych poglądów słuszny wydaje się ten trzeci. Będący postawą roszczenia art. 328 Poś zawiera odwołanie do art. 80 Poś, zgodnie z treścią którego: „reklama lub inny rodzaj promocji towaru lub usługi nie powinny zawierać treści propagujących model konsumpcji sprzeczny z zasadami ochrony śro-

3 Odnotować należy, że część doktryny nie wypowiada się w przedmiocie kategoryzacji spraw z art. 80 Poś, np. W. Radecki, Odpowiedzialność w ochronie środowiska, Wrocław 2002, s. 35; E. Radziszewski, Prawo ochrony środowiska. Przepisy i komentarz, Warszawa 2003, s. 355; K. Gruszecki, Prawo ochrony środowiska. Komentarz, Warszawa 2007, s. 656.

4 Tak: A. Lipiński, [w:] J. Jendrośka (red.), Ustawa Prawo ochrony środowiska. Komentarz, Wrocław 2001, s. 817; M. Bar, [w:] M. Górski et al., Prawo ochrony środowiska. Komentarz, Warszawa 2011, s. 1121-1122.

5 Szczegółowo: B. Rakoczy, Pojęcie sprawy gospodarczej z zakresu ochrony środowiska, „Przegląd Sądowy” 2003, nr 4, s. 77-90, a także B. Rakoczy, [w:] J. Ciechanowicz-McLean, Z. Bukowski, B. Rakoczy, Prawo ochrony środowiska. 2/2011 Komentarz, Warszawa 2008, s. 522. 
dowiska i zrównoważonego rozwoju, a w szczególności wykorzystywać obrazu dzikiej przyrody do promowania produktów i usług negatywnie wpływających na środowisko przyrodnicze".

Niewątpliwie za działalność zagrażającą środowisku określoną w art. $479^{1} \S 2$ pkt 2 k.p.c. można uznać reklamę towaru zawierającą treści propagujące model konsumpcji sprzeczny z zasadami ochrony środowiska i w związku z tym kwalifikacja przyjęta przez Sąd jest trafna ${ }^{6}$.

Na marginesie odnotować należy, że sprawy z zakresu ochrony środowiska są sprawami gospodarczymi wówczas, gdy stroną pozwaną jest przedsiębiorca, aczkolwiek warunek ten nie zachodzi po stronie powodowej, oraz gdy przedmiotem sporu jest m.in. sprawa o zakazanie lub ograniczenie działań zagrażających środowisku.

Z zainteresowaniem należy przyjąć próbę zakreślenia przez Sąd zasad odpowiedzialności w związku z naruszeniem art. 80 Poś. Sąd w tym zakresie poczynił szereg twierdzeń. Niemniej, nie bez znaczenia jest fakt, że ów przepis stanowi ograniczenie praw i wolności, gwarantowanych Konstytucją Rzeczypospolitej Polskiej z dnia 2 kwietnia 1997 r. ${ }^{8}$ Z drugiej jednak strony ustawodawca dopuszcza takie ograniczenie na podstawie art. 31 ust. 3 Konstytucji RP, który stanowi że: „ograniczenia w zakresie korzystania z konstytucyjnych wolności i praw mogą być ustanawiane tylko w ustawie i tylko wtedy, gdy są konieczne w demokratycznym państwie dla jego bezpieczeństwa lub porządku publicznego, bądź dla ochrony środowiska, zdrowia i moralności

6 Por. m.in. wyrok Sądu Apelacyjnego w Warszawie z dnia 8 grudnia 2009 r., sygn. VIA Ca 621/09, LEX 677994, oraz poprzedzający go w tej samej sprawie wyrok Sądu Okręgowego w Warszawie z dnia 30 września 2008 r., sygn. XX GC 854/07, a także wyrok Sądu Okręgowego w Warszawie z dnia 16 lutego 2009 r., sygn. XX Gc 738/07, poprzedzający wyrok Sądu Apelacyjnego w Warszawie, który to stanowi przedmiot niniejszej glosy.

7 K. Piasecki (red.), Kodeks postępowania cywilnego. Komentarz do artykutów 367-505 z ind. 37. Tom II, Warszawa 2010.

8 Dz. U. 1997, Nr 78, poz. 483 ze zm., dalej cyt.: Konstytucja RP. 
publicznej, albo wolności i praw innych osób. Ograniczenia te nie mogą naruszać istoty wolności i praw" .

Artykuł 80 Poś ogranicza wolność działalności gospodarczej, ale za jego dopuszczalnością przemawia wypełnienie konstytucyjnych warunków, to jest: ustanowienie w ustawie, wskazanie ochrony środowiska jako wartości nadrzędnej, a przy tym ograniczenie takie nie narusza istoty wolności działalności gospodarczej. Ma to jednak przełożenie na reguły wykładni prawa - każde ograniczenie praw i wolności winno być interpretowane zawężająco. Aczkolwiek w ochronie środowiska reguły wykładni językowej dość często okazują się być niewystarczające i z tego względu postuluje się badanie instytucji prawnych w ujęciu funkcjonalnym, tzn. poprzez udzielenie odpowiedzi na pytanie o ich rzeczywistą funkcję w życiu społecznym ${ }^{10}$.

Zwrócić należy uwagę na niejednorodny charakter art. 80 Poś, który stanowi: „reklama lub inny rodzaj promocji towaru lub usługi nie powinny zawierać treści propagujących model konsumpcji sprzeczny z zasadami ochrony środowiska i zrównoważonego rozwoju, a w szczególności wykorzystywać obrazu dzikiej przyrody do promowania produktów i usług negatywnie wpływających na środowisko przyrodnicze".

$\mathrm{Z}$ powyższego wynika, że z treści art. 80 Poś można wyprowadzić dwie niezależne od siebie normy, tj. 1) reklama lub inny rodzaj promocji towaru lub usługi nie powinny zawierać treści propagujących model konsumpcji sprzeczny z zasadami ochrony środowiska i zrównoważonego rozwoju oraz 2) reklama lub inny rodzaj promocji towaru lub usługi nie powinny w szczególności wykorzystywać obrazu dzikiej przyrody do promowania produktów i usług negatywnie wpływających na środowisko przyrodnicze.

Tylko pozornie może się wydawać, że jest to jednolity przepis, a jego druga część stanowi przykład, może nawet swoistą re-

9 Bardzo szczegółowo omawia tę problematykę: B. Rakoczy, Ograniczenie praw i wolności jednostki ze względu na ochronę środowiska w Konstytucji Rzeczypospolitej Polskiej, Toruń 2006.

10 K. Nowacki, Badania prawnoporównawcze $w$ ochronie środowiska, [w:] Nowe problemy badawcze $w$ teorii prawa administracyjnego, pod red. J. Bocia i A. Chajbowicza, Wrocław 2009, s. 128. 
gułę interpretacyjną, za czym przemawiać ma użycie formuły „W szczególności". Analiza jednak całego przepisu, przy założeniu racjonalności ustawodawcy, może prowadzić tylko do jednego wniosku: druga część przepisu stanowi kwalifikowaną postać zakazu.

W części pierwszej ustawodawca akcentuje treść reklamy w kontekście modelu konsumpcji, zaś w części drugiej - formę ${ }^{11}$. Pojęcie reklamy i zależność względem promocji wymienione art. 80 Poś były przedmiotem licznych analiz, podobnie zwracano uwagę na niejednolity charakter zasad ochrony środowiska ${ }^{12}$. Zwrócić jednak należy uwagę, że ochrona środowiska i zrównoważony rozwój ${ }^{13}$ nie stanowią wartości tożsamych, a przez to i zasady ochrony środowiska i zasada zrównoważonego rozwoju niejako konkurują ze sobą. Na marginesie odnotować tylko należy, że art. 31 ust. 3 Konstytucji RP dopuszcza ograniczenie praw i wolności z uwagi na ochronę środowiska, ale takiej wartości nie stanowi koncepcja zrównoważonego rozwoju i jej wdrażanie.

W drugiej części art. 80 Poś ustawodawca odwołuje się do wykorzystywania obrazu dzikiej przyrody do promowania produktów i usług negatywnie wpływających na środowisko przyrodnicze. Nie wyjaśnia przy tym jednakże znaczenia takich pojęć jak „obraz dzikiej przyrody”14, czy „środowisko przyrodnicze"15. Oba te pojęcia nie są charakterystyczne dla ustawy Prawo ochrony środowiska, aczkolwiek przedmiotowy zakaz został

11 Tak: D. Dziedzic-Chojnacka, D. Chojnacki, Zakaz reklamy nieekologicznej w polskim prawie ochrony środowiska, „Radca Prawny” 2007, z. 4, s. 61.

12 Por. zwłaszcza B. Rakoczy, [w:] J. Ciechanowicz-McLean, Z. Bukowski, B. Rakoczy, Prawo ochrony środowiska. Komentarz, Warszawa 2007, s. 189.

13 Szeroko nt. zrównoważonego rozwoju: Z. Bukowski, Zrównoważony rozwój w systemie prawa, Toruń 2009.

14 Szer. B. Rakoczy, [w:] J. Ciechanowicz-McLean, Z. Bukowski, B. Rakoczy, Prawo ochrony ..., s. 190-191, a także w kontekście reguł odpowiedzialności prawnej: J. Pakuła, Edukacja ekologiczna a zapobieganie szkodom w środowisku, [w:] Odpowiedzialność za szkodę w środowisku, pod red. B. Rakoczego, Toruń 2010, s. 250; M. Bar, [w:] M. Górski et al., Prawo ochrony środowiska..., s. 282-283.

15 Pojęcie „środowisko przyrodnicze” zdefiniowane zostało w art. 5 pkt 20 ustawy z dnia 16 kwietnia 2004 r. o ochronie przyrody, t.j. Dz. U. z 2009 r. Nr 151, poz. 1220 ze zm., gdzie oznacza ono: „krajobraz wraz z tworami przy- 
ustanowiony właśnie w tej ustawie. Wątpliwości budzi charakter tej części art. 80 Poś. Z jednej strony podaje się, że stanowi to jedynie przykład zakazanej reklamy, a „produkty i usługi negatywnie wpływające na środowisko przyrodnicze” mogą stanowić produkty i usługi o negatywnym wpływie podczas ich wytwarzania, użytkowania, a nawet po okresie użytkowania. Podaje się przy tym, że literalna wykładnia przepisu prowadzić będzie do całkowitej eliminacji z obrazu dzikiej przyrody w reklamie gospodarczej. Proponuje się również właściwą interpretację w ten sposób, że zakazane jest wykorzystanie obrazu dzikiej przyrody tylko w sytuacji, gdy reklama jednocześnie zawiera treści sprzeczne z zasadami ochrony środowiska i zasadą zrównoważonego rozwoju ${ }^{16}$.

Nie sposób jednak zgodzić się z przedstawioną argumentacją chociażby z tego względu, że nawet całkowita eliminacja obrazu dzikiej przyrody z reklamy towarów negatywnie wpływających na środowisko przyrodnicze nie uderza w istotę wolności działalności gospodarczej - nie zabrania się ani produkcji, ani sprzedaży takich towarów, a jedynie ogranicza się ich reklamę ze względu na konstytucyjnie chronione dobro. Podobne rozwiązania dotyczą reklamy zawodów prawniczych, wyrobów tytoniowych, alkoholu, czy gier ${ }^{17}$. Wyjaśnić przy tym należy, że taka eliminacja dotyczy tylko reklamy niektórych produktów (np. samochód, ale niekoniecznie już rower), a nie wystąpi na etapie produkcji. Przemawia za tym dość jasna konstrukcja przepisu: ustawodawca używa sformułowania „produkty”, a nie półprodukty, czy surowce, czy produkty zużyte, etc. Nie sposób również uzależniać tego od kumulacji naruszeń obu grup zasad: ochrony środowiska i zrównoważonego rozwoju. Tylko w ograniczonym stopniu będzie taka kumulacja występować, a trzeba

rody nieożywionej oraz naturalnymi i przekształconymi siedliskami przyrodniczymi z występującymi na nich roślinami, zwierzętami i grzybami".

16 D. Dziedzic-Chojnacka, D. Chojnacki, Zakaz reklamy..., s. 61-62.

17 Art. 29 ust. 1 ustawy z dnia 19 listopada 2009 r. o grach hazardowych, Dz. U. z 2009 r. Nr 201, poz. 1540 ze zm., stanowi, że: „zabrania się reklamy i promocji gier cylindrycznych, gier w karty, gier w kości, zakładów wzajem2/2011 nych oraz gier na automatach". 
mieć na uwadze, że wartości reprezentowane przez „środowisko przyrodnicze” wpisują się w koncepcję zrównoważonego rozwoju, ale nie są z nią tożsame. Wreszcie, charakter przepisu zdeterminowany jest przywołanym „środowiskiem przyrodniczym” i mimo że koncepcja zrównoważonego rozwoju wydaje się być dominującą, to jednak ustawodawca dopuszcza prymat ochrony przyrody ${ }^{18}$. W świetle powyższego należy uznać, że reklama produktów negatywnie wpływających na środowisko przyrodnicze jest dopuszczalna, aczkolwiek bez wykorzystania obrazu dzikiej przyrody. Nie sposób jednak przyjąć, że uzyskanie zezwoleń związanych z produkcją legalizuje ów produkt/towar i przez to nie wpływa negatywnie na środowisko przyrodnicze.

Odnosząc się do ustaleń Sądu, słusznie przyjął on, że dziś każda działalność człowieka, w tym przedsiębiorstwa, niesie za sobą zmiany w środowisku. Analizując treść uzasadnienia, należy zgodzić się z poglądem wyrażonym przez Sąd, iż zakaz wynikający z art. 80 Poś dotyczy treści reklamy, która nie powinna propagować określonego modelu konsumpcji, uznanego przez ustawodawcę za niepożądany, tj. sprzeczny z zasadami ochrony środowiska i zrównoważonego rozwoju. Wpisuje się to w pierwszą część art. 80 Poś. Trzeba jednak pamiętać, że reklamowany towar musi wpisywać się $\mathrm{w}$ model konsumpcji sprzeczny z zasadami ochrony środowiska i zrównoważonego rozwoju. Zastanawiano się, czy wykorzystywana często tzw. niemoc twórcza uzewnętrzniana nadprodukcją kulek z papieru wpisuje się w ów zakaz $^{19}$. Wyraźnie należy stwierdzić, że nie wpisuje się, o ile przedmiot reklamy sprawia, że bohater odzyskuje siły. Przykładem takiej reklamy może być reklama samochodu terenowego, która zachęca do brawurowej jazdy po terenie parku narodowego, niszcząc roślinność, czy płosząc zwierzęta.

18 W wyroku z dnia 28 kwietnia 2010 r. NSA, sygn. II OSK 720/09, LEX nr 597808, przyjął, że: „1. W otulinie parku krajobrazowego może być prowadzona tylko taka działalność, która dla parku krajobrazowego nie stwarza zagrożenia wynikającego z określonej działalności człowieka. 2. O niemożności zaakceptowania konkretnej działalności na terenie otuliny przesądza brak możliwości pogodzenia jej z funkcją ochronną otuliny".

19 D. Dziedzic-Chojnacka, D. Chojnacki, Zakaz reklamy..., s. 61. 
Pozytywnie również należy zapatrywać się na pogląd wyrażony przez Sąd, że roszczenie o zaniechanie reklamy, promocji produktu przysługuje tylko w takiej sytuacji, gdy podmiot reklamujący rozpowszechnia, popiera, propaguje model konsumpcji sprzeczny z zasadami ochrony środowiska i zrównoważonego rozwoju. Konieczne jest opublikowane reklamy, czy to w prasie, czy w telewizji lub radiu.

Sąd prawidłowo przyjął, że warunkiem, bez zaistnienia którego roszczenie nie może być dochodzone, jest wykazanie, że reklama propaguje taki model konsumpcji, który nie tylko wpływa na środowisko, ale niszczy je, degraduje, prowadzi do zaburzenia równowagi w przyrodzie. O ile każda działalność ma dziś wpływ na stan środowiska, to nie każdy taki wpływ musi mieć charakter negatywny. Zmiany mogą być wywołane działalnością gospodarczą, ale także zwyczajnym działaniem człowieka. Ustawodawca również jest tego świadom i z tego względu zresztą wyróżnia korzystanie ze środowiska: powszechne i zwykłe ${ }^{20}$.

Zaaprobować należy również stanowisko wyrażone przez Sąd Apelacyjny, że dla zastosowania art. 80 Poś wystarczające jest wykorzystanie obrazu, który w powszechnym odbiorze stanowi element dzikiej przyrody, nawet jeśli przedstawienie danego elementu dzikiej przyrody następuje poprzez piktogram. W tym zakresie odmienne zdanie miał Sąd I instancji, który opowiedział się, że musi to być naturalny obraz dzikiej przyrody. Należy jednak tutaj odwołać się do celowości rozwiązania, zwłaszcza w dobie kreskowej grafiki, komiksu i gier komputerowych. Przy przeciwnym założeniu, dość łatwo ograniczyć odpowiedzialność z tytułu naruszenia nakazu z art. 80 Poś.

Kontrowersje wzbudza jednak założenie Sądu, że między dwoma zdarzeniami - tj. reklamą lub innym rodzajem promocji produktu lub towaru a negatywnym wpływem na środowisko - musi istnieć normalny związek przyczynowy, gdzie zdarzenie późniejsze stanowi skutek, będący następstwem zdarzenia wcześniejszego, tj. przyczyny, i przez to w przedmiotowej sprawie nie

20 Ustawodawca również wprowadził specjalną kategorię: podmiot korzystający ze środowiska. Zob. B. Rakoczy, [w:] B. Wierzbowski, B. Rakoczy, Prawo ochrony środowiska. Zagadnienia podstawowe, Warszawa 2010, s. 89 i nast. 
istnieje „normalne” następstwo pomiędzy udzieleniem kredytu a degradacją środowiska. Po pierwsze, o ile Sąd nie dostrzegł takiego związku, to jednak może zaistnieć taka szkoda i wbrew pozorom, przy odpowiedniej reklamie jest to możliwe. Wystarczy bowiem przedstawić reklamę, której przedmiotem jest kredyt lub pożyczka, a bank zachęca do wydatkowania tychże środków na niczym nieograniczone spędzenie czasu w parku narodowym. Zwrócić należy uwagę, że w kontekście odpowiedzialności z art. 80 Poś wystarczy już samo ryzyko wystąpienia szkody - czyli reklama propagująca model konsumpcji sprzeczny z zasadami ochrony środowiska i zrównoważonego rozwoju - a nie zaistnienie takiej szkody. Zresztą art. 80 Poś wpisuje się dość mocno w zasady: przezorności i prewencji.

Zauważyć również należy, iż Sąd podjął się rozważań nad „duchem” ustawy Prawo ochrony środowiska. Słusznie Sąd przyjął, że nie chodzi o to, aby zabronić prawa do korzystania ze środowiska, ale aby korzystać z niego w określonych granicach. Wymaga to jednak edukacji społeczeństwa, o czym ustawodawca pamięta. Można wyodrębnić edukację systemową (szkolnictwo), edukację pozasystemową (zajęcia pozaszkolne, cechujące się pewnym stopniem zorganizowania ze względu na krąg adresatów) oraz edukację nieformalną (środki masowego przekazu) ${ }^{21}$. Również polski ustawodawca dostrzega ten podział i uwzględnia w dziale VIII tytułu I Poś, który jest poświęcony edukacji ekologicznej, badaniom z zakresu ochrony środowiska oraz reklamie. Świadom jest on wpływu środków masowego przekazu, a także reklamy i promocji. Istota reklamy i promocji, pomijając już przytaczanie definicji obu ${ }^{22}$, sprowadza się do zachęcenia konsumenta do zakupu, a przez to niezwykle działa na adresata. Adresatem jest „każdy”, bez względu na jakiekolwiek cechy i różnice. $\mathrm{Z}$ tego też względu ustawodawca z jednej strony

21 L. Giuffre, S. Formento, S. Ratto, Transversalidad de conceptos de educacion ambiental para un desarrollo sostenible presentes en la legislacion Argentina, "Ciencia del Suelo", Jul 2007, Vol. 25, Issue 1, s. 75.

22 Szer. B. Rakoczy, [w:] J. Ciechanowicz-McLean, Z. Bukowski, B. Rakoczy, Prawo ochrony..., s. 188-189; D. Dziedzic-Chojnacka, D. Chojnacki, Zakaz reklamy..., s. 53-58. 
zakazuje kształtowania negatywnych postaw, a z drugiej zachęca do aktywnego udziału szeroko rozumiane media $\mathrm{w}$ procesie kształtowania świadomości ekologicznej. Jest to o tyle istotne, że stan edukacji zwłaszcza formalnej można oceniać bardzo różnie, $\mathrm{z}$ naciskiem na brak efektywności. W reklamie i promocji - zarówno w telewizji, w radiu, czy w prasie - ustawodawca upatruje swoiste wsparcie, a także istotny ośrodek kształtowania postaw środowiskowych. Z tego względu reklama i promocja wpisują się w proces edukacji ekologicznej społeczeństwa. Taka była intencja ustawodawcy, skoro bowiem zaliczył reklamę do działu VIII tytułu I ustawy Prawo ochrony środowiska. Zresztą celem edukacji ekologicznej jest szeroko rozumiane racjonalne korzystanie ze środowiska.

W świetle powyższych uwag należy odnieść się również wprost do zasady proporcjonalności w związku z art. 80 Poś $^{23}$. Kluczowe staje się pytanie, czy rzeczywiście konieczne jest wprowadzenie takiego zakazu. Celem jest podniesienie stanu świadomości ekologicznej, a przez to poziomu ochrony środowiska. Może to nastąpić przez zaniechanie kształtowania postaw negatywnie wpływających na środowisko i kształtowanie zachowania przyjaznego dla środowiska. Ustawodawca dostrzega rolę mediów, a przez to ma na uwadze reklamę i promocję, a stanowi o tym okoliczność, że art. 80 znajduje się w dziale VIII tytułu I Poś. Z tego względu przyjąć należy, że reklama i promocja mogą wykonywać zadania z zakresu edukacji ekologicznej - zwłaszcza wśród wszystkich tych osób, u których edukacja systemowa (formalna) nie wywołuje zamierzonego celu z różnych powodów. Przy uwzględnieniu tych celów można przyjąć, że zastosowane środki w postaci zakazu art. 80 Poś nie są zbyt uciążliwe dla jednostki, a przy tym trudno mówić o innej drodze do osiągnięcia tego celu - zwłaszcza gdy reklama jest istotnym kanałem edukacji dla dorosłych.

Podsumowując, przyznać należy, że przedmiotowy wyrok odpowiada prawu. Wydaje się, że również uzasadnienie, mimo pewnych wątpliwości zasługuje na uwagę z przywołanych na 
wstępie względów. Zakwalifikowanie spraw z art. 80 Poś jako spraw gospodarczych ma realne przełożenie na prekluzję dowodową, a przez to prowadzi do wyspecjalizowania - a także przyspieszenia - postępowania. Niemniej, w niedalekiej przyszłości sądy będą musiały rozstrzygnać o charakterze norm art. 80 Poś. Nie ulega bowiem wątpliwości, że wraz z podnoszeniem świadomości ekologicznej wzrośnie liczba takich spraw. Można przewidzieć, że sędziowie włączeni zostaną w proces wyspecjalizowanej edukacji ekologicznej. Nawet jeśli również przedsiębiorcy, a zwłaszcza producenci i emitenci reklam poddani zostaną skutecznej edukacji ekologicznej, to niewątpliwie tzw. zakaz reklamy nieekologicznej nie stanie się zbędny.

Kontakt e-mail:

jacekpakula@gmail.com 